\title{
PERBEDAAN KEMAMPUAN KOMUNIKASI MATEMATIS SISWA MELALUI PENDEKATAN PEMBELAJARAN OPEN ENDED DENGAN PENDEKATAN PEMBELAJARAN DIFFERENTIATED INSTRUCTION BERBANTUAN WINGEOM DI SMP NEGERI 1 TANJUNG MORAWA
}

\author{
Mawaddah, Erlinawaty Simanjuntak \\ E-mail :mawaddah@gmail.com \\ Prodi Pendidikan Matematika, FMIPA Universitas Negeri Medan
}

\begin{abstract}
ABSTRAK
Jenis penelitian ini adalah eksperimen semu. Penelitian ini bertujuan untuk mengetahui adanya perbedaan kemampuan komunikasi matematis antara siswa yang diajar menggunakan pendekatan openended berbantuan wingeom dengan siswa yang diajar menggunakan pendekatan differentiated instruction berbantuan wingeom di kelas VIII SMP Negeri 1 Tanjung Morawa. Populasi dalam penelitian ini adalah seluruh kelas VIII yang berjumlah 9 kelas kemudian dilakukan pengambilan sampel dengan menggunakan teknik random sampling. Sampel yang diambil sebanyak 2 kelas yaitu kelas VIII-1 dan VIII-2 yang masing-masing berjumlah 36 siswa. Instrumen pengumpulan data yang digunakan adalah pretest dan posttest yang berbentuk uraian soal. Pretest digunakan untuk mengetahui kemampuan awal siswa. Sedangkan posttest digunakan untuk mengetahui perbedaan kemampuan komunikasi matematis siswa setelah diberikan perlakuan yang berbeda. Pengujian hipotesis yang digunakan adalah uji t 2 pihak dengan $d k=70$ dan $\alpha=0,05$, maka diperoleh $t_{\text {hitung }}=2,407$ dan $t_{\text {tabel }}=1,994$ sehingga $t_{\text {hitung }}>t_{\text {tabel }}$ yaitu 2,407>1,994 maka Ha diterima, dengan demikian diperoleh kesimpulan bahwa terdapat perbedaan kemampuan komunikasi matematis siswa yang diajarkan dengan pendekatan pembelajaran Open Ended berbantuan wingeom dengan pendekatan pembelajaran Differentiated Instruction berbantuan wingeom.
\end{abstract}

Kata Kunci : Open Ended, Differentiated Instruction, Komunikasi Matematis, Wingeom

\section{ABSTRACT}

The type of this research is quasi-experiment. This study aims to determine the differences in the ability of mathematical communication between students taught using the open ended approach wingeom assisted with students taught using a differentiated instruction approach wingeom assisted at grade VIII SMP Negeri 1 Tanjung Morawa. Population in this research is all class VIII which amounts to 9 class then do sampling by using random sampling technique. Samples taken as many as 2 classes of classes VIII1 and VIII-2, each of which amounted to 36 students. The instrument of data collection used is pretest and posttest which in the form of problem description. Pretest is used to determine students' early skills. While posttest is used to know the difference of students'

Mawaddah, Erlinawaty Simanjuntak Perbedaan Kemampuan Komunikasi Matematis Siswa Melalui Pendekatan Pembelajaran Open Ended Dengan Pendekatan Pembelajaran Differentiated Instruction Berbantuan Wingeom di SMP Negeri I Tanjung Morawa. Jurnal Inspiratif, Vol. 4, No. 2 Agustus 2018.

Page 37 
mathematical communication ability after given different treatment. The data analysis of experimental class by using $t$-test two tail with $d k=70$ and significance level $\alpha=0.05$, it was obtained that $t_{\text {calculation }}=2,407$ and $t_{\text {table }}=1,994$ so $t_{\text {calculation }}>t_{\text {table }}$ then $H_{0}$ is rejected and $H_{a}$ is accepted. The result showed that there is different in student's mathematical communications skill with by using Open Ended scientific approach aided Wingeom and Differentiated Instruction scientific approach aided Wingeom.

Keyword : Open Ended, Differentiated Instruction, Mathematical Communications, Wingeom

\section{PENDAHULUAN}

Matematika merupakan ilmu yang penting yang mendasari perkembangan teknologi pada zaman modern, matematika juga salah satu ilmu yang banyak dimanfaatkan dalam kehidupan sehari-hari. Maka penguasaan matematika harus diperkuat sejak dini. Semua orang diharapkan dapat menggunakan bahasa matematika untuk mengungkapkan ide/gagasan yang dimilikinya. Matematika merupakan sarana komunikasi sains tentang polapola yang berguna untuk melatih berpikir kritis, logis, kreatif dan inovatif. Banyak persoalan yang disampaikan dengan bahasa matematika, misalnya dengan menyajikan persoalan atau masalah ke dalam model matematika yang dapat berupa diagram, persamaan matematika, grafik dan tabel. Salah satu tujuan dari pembelajaran matematika adalah memiliki kecakapan dan kemampuan dalam komunikasi matematis. Hal ini karena melalui komunikasi matematis siswa dapat mengorganisasikan berpikir matematisnya baik secara lisan maupun tulisan, di samping itu siswa juga dapat memberikan respon yang tepat antar siswa dan media dalam proses pembelajaran. Bahkan dalam pergaulan masyarakat, seseorang yang mempunyai kemampuan komunikasi yang baik akan cenderung lebih mudah beradaptasi dengan siapa pun dimana dia berada dalam suatu komunitas, yang pada gilirannya akan menjadi seseorang yang berhasil dalam hidupnya (Umar, 2012).
Menurut Depdiknas (dalam Risqi \& Surya, 2017) bahwa salah satu tujuan pembelajaran matematika di sekolah adalah untuk melatih pola pikir dan penalaran dalam mengambil kesimpulan mengembangkan kemampuan untuk memecahkan masalah, dan mengembangkan kemampuan untuk memberikan informasi atau mengkomunikasikan gagasan melalui lisan, tertulis, gambar, grafik, peta , diagram, dll.

Namun pada kenyataan dilapangan kebanyakan siswa tidak bisa menyelesaikan soal cerita. Ketika soal dihadapkan dengan bentuk cerita siswa bingung harus menyelesaikan yang mana. Dari hasil observasi yang dilakukan di kelas VIII terhadap siswa SMP Negeri 1 Tanjung Morawa menunjukkan bahwa kemampuan komunikasi matematis siswa masih rendah terlihat dari tes diagnostik terhadap siswa kelas VIII.

Disisi lain, sistem pembelajaran yang digunakan guru kurang menarik perhatian siswa dalam proses pembelajaran, sehingga mengakibatkan siswa terlalu mudah jenuh dan mudah bosan. Dari observasi yang telah dilakukan didapat temuan sebagai berikut : (1) tidak jarang guru masih menggunakan metode ceramah sehingga siswa dikelas terkesan pasif; (2) siswa diberi soal uraian saat observasi, kemampuan siswa untuk menjelaskan langkah yang dikerjakan masih sangat rendah; (3)

Mawaddah, Erlinawaty Simanjuntak Perbedaan Kemampuan Komunikasi Matematis Siswa Melalui Pendekatan Pembelajaran Open Ended Dengan Pendekatan Pembelajaran Differentiated Instruction Berbantuan Wingeomdi SMP Negeri I Tanjung Morawa. Jurnal Inspiratif, Vol. 4, No. 2 Agustus 2018. 
siswa lebih monoton pada rumus dan contoh soal yang ada; (4) sebagian siswa memiliki mindset bahwa matematika itu pelajaran yang sulit untuk difahami sehingga mareka kurang aktif dalam kegiatan belajar mengajar.

Selanjutnya, dilihat bahwa sebagian besar pola pembelajaran masih menggunakan metode ceramah, pengajar mentransfer dan menerapkan konsepkonsep secara langsung pada peserta didik. Dalam pandangan ini, siswa secara pasif menyerap struktur pengetahuan yang diberikan guru atau yang terdapat dalam buku pelajaran.Pandangan konstruktivisme memberikan perbedaan yang kontras terhadap pandangan tersebut. Sebagaimana yang dikemukakan oleh Suparno (dalam Trianto, 2009:18) prinsip dasar konstruktivisme itu antara lain:

(1) pengetahuan dibangun oleh siswa sendiri,baik secara personal maupun secara sosial, (2) pengetahuan tidak dapat dipindahkan dari guru ke siswa kecuali dengan keaktifan siswa menalar, (3) siswa aktif mengkonstruksi terus-menerus, sehingga selalu terjadi perubahan konsep ilmiah, (4) guru berperan sebagai fasilitator menyediakan sarana dan situasi agar proses konstruksi pengetahuan siswa berjalan mulus.

Dari kutipan di atas dapat disimpulkan bahwa pentingnya interaksi dalam proses belajar. Seperti yang kemukakan oleh Vygotsky (dalam Trianto, 2009:19), ia menyatakan "belajar adalah proses sosial konstruksi yang dihubungkan oleh bahasa dan interaksi sosial". Kurangnya interaksi antara guru dengan siswa, siswa dengan siswa dan siswa dengan sumber maupun media belajar dalam kegiatan pembelajaran menyebabkan kurangnya kemampuan psikomotor dan afektif siswa. Siswa jarang berdiskusi dan bekerja sama dengan siswa lain yang mengakibatkan siswa menjadi pasif, keterampilan proses sains tidak berkembang, dan sikap ilmiah siswa kurang.

Selanjutnya langkah yang bisa dilakukan oleh guru sebagai pembimbing adalah memilih strategi atau pendekatan yang dinilai efektif sehingga tercipta suasana belajar yang kondusif dan memberi kesempatan siswa dalam berkomunikasi matematis untuk menyampaikan informasi, seperti menyatakan ide, mengajukan pertanyaan, memodelkan soal cerita kedalam model matematika dan menanggapi pertanyaan orang lain. Dengan demikian, ada beberapa pendekatan model pembelajaran diantaranya adalah pendekatan Open Ended dan Differentiated Instruction.

Suatu pendekatan pembelajaran yang menuntut keterlibatan aktif siswa dan dapat meningkatkan kemampuan siswa dalam memecahkan masalah. Salah satunya dengan pendekatan pembelajaran open ended. Strategi pembelajaran pedekatan open ended adalah salah satu strategi yang diharapkan mencapai tujuan di atas, yaitu melatih siswa untuk menemukan dan mengkonstruksikan pengetahuan dan pengalaman belajar siswa untuk menyelesaikan soal. Karakter pendekatan open ended, dimana proses penyelesaian soal yang terbuka dan multi jawaban mungkin, akan meningkatkan kemampuan siswa khususnya komunikasi matematis siswa. Hal ini senada dengan Ahmad Afandi dan Dhoriva Urwatul Wustqa (2013) bahwa pada pendekatan open-ended formulasi masalah yang digunakan adalah masalah terbuka.

Differentiated Instruction (DI) adalah cara untuk menyesuaikan instruksi kepada kebutuhan siswa

Mawaddah, Erlinawaty Simanjuntak Perbedaan Kemampuan Komunikasi Matematis Siswa Melalui Pendekatan Pembelajaran Open Ended Dengan Pendekatan Pembelajaran Differentiated Instruction Berbantuan Wingeomdi SMP Negeri I Tanjung Morawa. Jurnal Inspiratif, Vol. 4, No. 2 Agustus 2018. 
dengan tujuan memaksimalkan potensi masing-masing siswa dalam lingkup yang diberikan. Mengenai DI menurut Evi Lailiyah (2016) menyatakan bahwa dengan pendekatan Differentiated Instruction siswa belajar sesuai dengan gaya belajar, tingkat kesiapan, ataupun ketertarikan mereka terhadap sesuatu. Sehingga diharapkan ide-ide kreatif mereka dapat bermunculan karena proses pembelajaran yang disesuaikan dengan keinginan dan kebutuhan mereka. Menurut Evi Lailiyah (2016) walaupun model pengajaran ini berorientasi pada perbedaan-perbedaan individual anak, namun tidak berarti pengajaran harus berdasarkan prinsip satu orang guru dengan satu orang murid.

Dari penjelasan di atas, pendekatan pembelajaran open ended dan differentiated instruction diharapkan dapat membangkitkan ketertarikan siswa untuk belajar matematika, serta membuat siswa lebih aktif dan mendorong kerjasama yang baik antar siswa dalam mempelajari dan memecahkan masalah yang ada khususnya pada materi kubus dan balok. selain itu, adanya ketertarikan untuk lebih mengatahui pendekatan pembelajaran mana yang efektif diajarkan dalam meningkatkan komunikasi matematis siswa.

Cara lain yang juga direncanakan akan digunakan guru adalah dengan menggunakan bantuan teknologi. Perkembangan dalam bidang teknologi informasi dapat meningkatkan pembaharuan media belajar yang lebih cocok, menarik bagi siswa, rasa ketertarikan dan minat. Jenis teknologi yang akan digunakan adalah dengan bantuan Software Wingeom. Wingeom adalah Open Source Software yang banyak dipakai didunia pendidikan matematika sebagai bahan ajar matematika.
Program Wingeom merupakan salah satu perangkat lunak komputer matematika dinamik (dynamic mathematics software) untuk topik geometri. Program ini dapat digunakan untuk membantu pembelajaran geometri dan pemecahan masalah geometri. Mengenai Wingeom menurut Ketut Sutama, dkk (2014) bahwa "bagianbagian geometri mulai dari yang paling sederhana hingga yang paling sulit dapat disajikan melalui program ini". Selain itu, khusus untuk ruang dimensi tiga tepatnya materi kubus dan balok, program ini mampu menampilkan gambar yang bisa diputar secara vertikal ataupun horizontal sehingga mampu membantu visualisasi siswa.

\section{METODE PENELITIAN}

Jenis penelitian ini adalah eksperimen semu. Penelitian ini dilakukan di SMP Negeri 1 Tanjung Morawa. Populasi dalam penelitian ini adalah seluruh kelas VIII SMP Negeri 1 Tanjung Morawa yang berjumlah 9 kelas, kemudian dilakukan pengambilan sampel dengan menggunakan teknik random sampling. Sampel yang diambil sebanyak 2 kelas yaitu kelas VIII-1 dan VIII-2 yang masing-masing berjumlah 36 siswa dan diberikan perlakuan yang berbeda. Kelas eksperimen I diajar dengan menggunakan pendekatan Open Ended berbantuan wingeom dan kelas eksperimen II diajar dengan menggunakan pendekatan Differentiated Instructionberbantuan wingeom.

Instrumen pengumpulan data yang digunakan adalah pretest dan posttest yang berbentuk uraian soal terdiri dari 4 butir. Pretest digunakan untuk mengetahui kemampuan awal siswa. Sedangkan posttest digunakan untuk mengetahui kemampuan komunikasi matematis siswa setelah diberikan perlakuan. Dalam penelitian ini data yang akan diolah adalah selisih antara

Mawaddah, Erlinawaty Simanjuntak Perbedaan Kemampuan Komunikasi Matematis Siswa Melalui Pendekatan Pembelajaran Open Ended Dengan Pendekatan Pembelajaran Differentiated Instruction Berbantuan Wingeomdi SMP Negeri I Tanjung Morawa. Jurnal Inspiratif, Vol. 4, No. 2 Agustus 2018. 
nilai pretest dan posttest siswa. Kemudian data tersebut dianalisis dengan menggunakan uji hipotesis yaitu Uji-T 2 pihak. Sebelum uji hipotesis terlebih dahulu dilakukan uji normalitas data dan homogenitas varians.

\section{HASIL PENELITIAN}

Data kemampuan komunikasi matematis siswa dari nilai posttest siswa. Data nilai posttest disajikan pada Tabel 1 berikut.

Tabel 1 Data Nilai Posttest Kelas Eksperimen I dan Kelas Eksperimen II

\begin{tabular}{|clcc|}
\hline No & \multicolumn{1}{c}{ Statistik } & Kelas Eksperimen I & Kelas Eksperimen II \\
\hline $\mathbf{1}$ & N & 36 & 36 \\
\hline $\mathbf{2}$ & Jumlah Nilai & 2904,87 & 2634,87 \\
\hline $\mathbf{3}$ & Rata-rata & 80,69 & 73,19 \\
\hline $\mathbf{4}$ & Simpangan Baku & 11,69 & 9,91 \\
\hline $\mathbf{5}$ & Varians & 136,73 & 98,15 \\
\hline $\mathbf{6}$ & Maksimum & 96,66 & 93,33 \\
\hline $\mathbf{7}$ & Minimum & 50 & 51,66 \\
\hline
\end{tabular}

ini:

Untuk lebih jelasnya nilai Posttest kedua kelas disajikan dalam diagram berikut

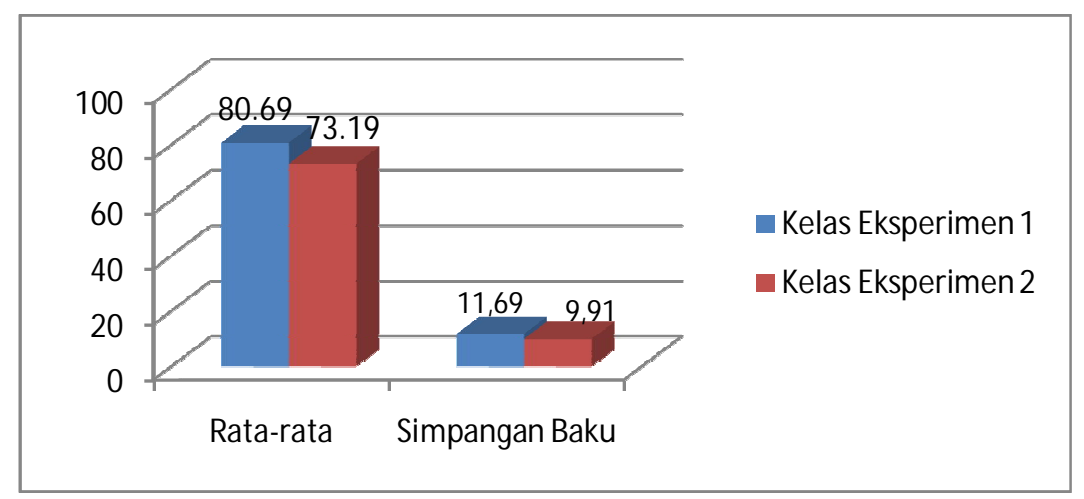

Gambar 1 Diagram Rata-rata dan Simpangan Baku Data Posttest

Data posttest siswa mendeskripsikan tingkat kemampuan komunikasi matematis siswa. Dari hasil posttest yang diberikan, data kemampuan rata- rata siswa dalam setiap aspek komunikasi matematis disajikan dalam Tabel 2 berikut.

Tabel 2 Data Kemampuan Rata-rata Siswa dalam Setiap Aspek Komunikasi Matematis Kelas Eksperimen I dan Kelas Eksperimen II

\begin{tabular}{|cccc|}
\hline No & $\begin{array}{c}\text { Indikator Kemampuan } \\
\text { Komunikasi Matematis Siswa }\end{array}$ & $\begin{array}{c}\text { Kelas Eksperimen } \\
\text { I }\end{array}$ & $\begin{array}{c}\text { Kelas Eksperimen } \\
\text { II }\end{array}$ \\
\hline $\mathbf{1}$ & Refresentasi & $78,27 \%$ & $68,25 \%$ \\
\hline $\mathbf{2}$ & Membaca & $90,63 \%$ & $84,03 \%$ \\
\hline $\mathbf{3}$ & Menulis & $74,13 \%$ & $71,01 \%$ \\
\hline
\end{tabular}

Data selisih nilai posttestpretest kelas eksperimen I dan kelas eksperimen II. Data selisih posttestpretest ini yang akan diolah untuk menerima atau menolak hipotesis penelitian.Secara ringkas hasil selisih posttest-pretest kedua kelas diperlihatkan pada tabel berikut:

Mawaddah, Erlinawaty Simanjuntak Perbedaan Kemampuan Komunikasi Matematis Siswa Melalui Pendekatan Pembelajaran Open Ended Dengan Pendekatan Pembelajaran Differentiated Instruction Berbantuan Wingeomdi SMP Negeri I Tanjung Morawa. Jurnal Inspiratif, Vol. 4, No. 2 Agustus 2018. 
Tabel 3 Data Nilai Selisih Posttest-Pretest Kelas Eksperimen I dan Kelas Eksperimen II

\begin{tabular}{|clcc|}
\hline No & \multicolumn{1}{c}{ Statistik } & Kelas Eksperimen I & Kelas Eksperimen II \\
\hline $\mathbf{1}$ & N & 36 & 36 \\
\hline $\mathbf{2}$ & Jumlah Nilai & 958,19 & 694,4 \\
\hline $\mathbf{3}$ & Rata-rata & 26,62 & 19,29 \\
\hline $\mathbf{4}$ & Simpangan Baku & 14,14 & 11,58 \\
\hline $\mathbf{5}$ & Varians & 199,84 & 134,08 \\
\hline $\mathbf{6}$ & Maksimum & 55,52 & 45,41 \\
\hline $\mathbf{7}$ & Minimum & 4,16 & 3,44 \\
\hline
\end{tabular}

Untuk lebih jelasnya nilai

selisih Posttest-Pretest kedua kelas

disajikan dalam diagram berikut ini:

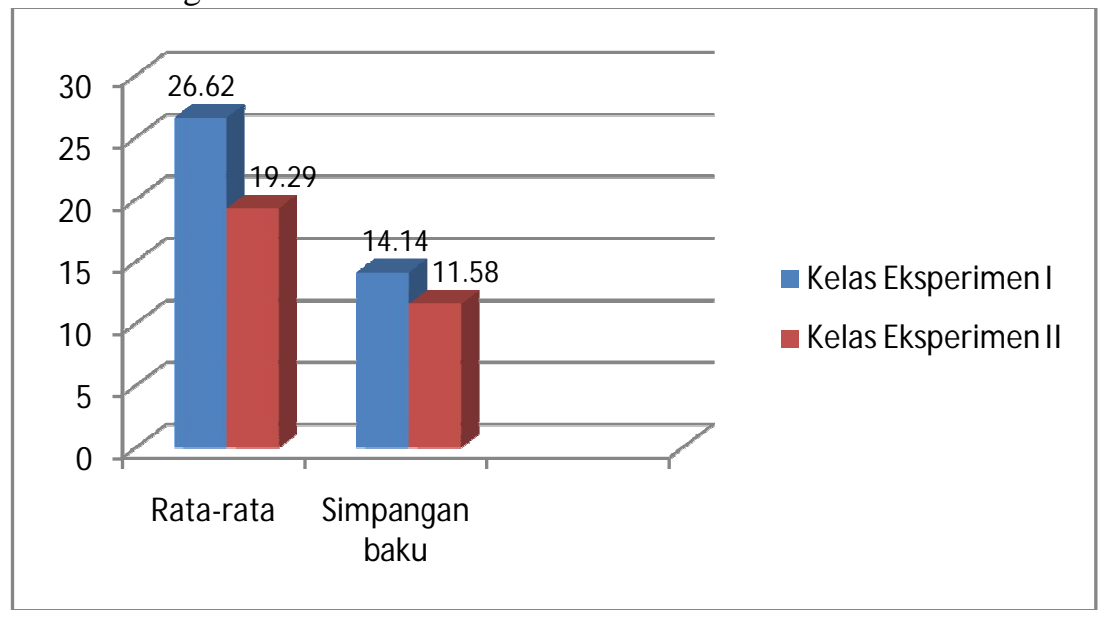

Gambar 2Diagram Rata-rata dan Simpangan Baku Data SelisihPosttestPretest

Setelah dilakukan uji normalitas dffaa: $\mu_{1}$ dan homogenitas varians, diperoleh bahwa kedua sampel berdistribusi normal dan mempunyai varians yang sama besar dan berasal dari populas yang homogen, maka selanjutnya dilakukan uji hipotesis menggunakan uji-T 2 pihak dengan $\mathrm{dk}=\left(\mathrm{n}_{1}+\mathrm{n}_{2}-2\right)$, peluang $(1-1 / 2 \alpha)$ dan taraf nyata $\alpha=$ 0,05 , kriteria pengujian adalah sebagai berikut

1. Jika $t_{\text {hitung }}<t_{\text {tabel }}$ maka $\mathrm{H}_{0}$ diterima

2. Jika $t_{\text {hitung }} \geq t_{\text {tabel }}$ maka $\mathrm{H}_{0}$ ditolak Hipotesis dalam penelitian ini adalah:
$H o=\mu_{2} \quad: \quad$ Tidak terdapat perbedaan kemampuan komunikasi matematis siswa yang diajar menggunakan Pendekatan Openended berbantuan wingeom dengan kemampuan komunikasi matematis siswa yang diajar dengan Pendekatan Differentiated Instruction berbantuan wingeom.

$\mathrm{H}_{\mathrm{a}}: \mu_{1} \neq \mu_{2} \quad: \quad$ terdapat perbedaan kemampuan komunikasi matematis siswa yang diajar menggunakan Pendekatan Open-ended berbantuan wingeom dengan kemampuan komunikasi matematis siswa yang diajar dengan pendekatan

Mawaddah, Erlinawaty Simanjuntak Perbedaan Kemampuan Komunikasi Matematis Siswa Melalui Pendekatan Pembelajaran Open Ended Dengan Pendekatan Pembelajaran Differentiated Instruction Berbantuan Wingeom di SMP Negeri I Tanjung Morawa. Jurnal Inspiratif, Vol. 4, No. 2 Agustus 2018. 
Differentiated

Instruction

berbantuan wingeom.

Dari analisis data posttestpretest siswa diperoleh bahwa $\mathrm{t}_{\text {hitung }}=$
2,407 sedangkan dalam daftar distribusi $\mathrm{t}$ diperoleh $\mathrm{t}_{\text {tebel }}=1,994$, maka $\mathrm{t}_{\text {hitung }}>$ $\mathrm{t}_{\text {tabel }}=2,407>1,994$ maka ditolak $\mathrm{H}_{0}$ atau terima $\mathrm{H}_{\mathrm{a}}$. Ringkasan hasil uji hipotesis disajikan dalam tabel 4

Tabel 4 Ringkasan Perhitungan Uji Hipotesis Data Selisih Posttest-Pretest

\begin{tabular}{|c|l|c|c|c|c|}
\hline \multirow{2}{*}{ Uji dua pihak } & Data Kelas & Rata-rata & $\mathbf{t}_{\text {hitung }}$ & $\mathbf{t}_{\text {tabel }}$ & Kesimpulan \\
\cline { 2 - 4 } & Eksperimen I & 26,62 & 2,407 & 1,994 & Terima $\mathrm{H}_{\mathrm{a}}$ \\
\cline { 2 - 3 } & Eksperimen II & 19,29 & & & \\
\hline
\end{tabular}

\section{PEMBAHASAN}

Melihat hasil penelitian yang dikemukakan di atas menunjukkan bahwa terdapat perbedaan kemampuan komunikasi matematis siswa yang diajar dengan pendekatanOpen Ended berbantuan wingeom dengan kemampuan komunikasi matematis siswa yang diajar dengan pendekatan Differentiated Instruction berbantuan wingeom di SMP Negeri 1 Tanjung Morawa. Karena rata-rata nilai kemampuan komunikasi matematis siswa yang diajar dengan pendekatan Open Endedberbantuan wingeom adalah 26,62 dan lebih tinggi dibandingkan kemampuan komunikasi matematis siswa yang diajar dengan pendekatan Differentiated Instruction berbantuan wingeom dengan nilai rata-rata 19,29. Sehingga kemampuan komunikasi matematis siswa yang diajar dengan pendekatan Open Ended berbantuan wingeom lebih baik daripada kemampuan komunikasi matematis siswa yang diajar dengan pendekatan Differentiated Instruction berbantuan wingeom.

Hasil penelitian ini didukung dan diperkuat dengan penelitian yang terdahulu yaitu Hefni Lidia Lubis(2015) yang menyimpulkan bahwa kemampuan pemecahan masalah matematis siswa dengan pembelajaran open ended lebih baik dibandingkan dengan pembelajaran konvensional. Raden dan Idris juga menyimpulkan bahwa terdapat perbedaan keefektifan secara signifikan pada penerapan pendekatan open ended dan pendekatan kontekstual dalam pemebelajaran matematika materi pokok bangun ruang sisi datar pada aspek kemampuan pemecahan masalah matematis dan sikap siswa terhadap matematika, dari hasi uji lanjut menunjukkan bahwa : (a) pendekatan open ended lebih efektif dibandingkan pendekatan kontekstual pada aspek kemampuan pemecahan masalah matematis siswa, (b) pendekatan open ended tidak lebih efektif dibandingkan pendekatan kontekstual pada aspek sikap siswa terhadap matematika.

Pinter (dalam Simamora et al., 2017) menyatakan bahwa kemampuan menyelesaikan masalah adalah keterampilan yang sangat penting. Dengan kemampuan memecahkan masalah matematika siswa akan dapat mengatur situasi kehidupan nyata dalam model matematika. Kemampuan pemecahan masalah itu sendiri bukan hanya tujuan dalam belajar matematika, tetapi juga sesuatu yang sangat berarti dalam kehidupan sehari-hari, dan dalam dunia kerja, tenjadi pemecah masalah dapat memberikan manfaat atau keuntungan.

Dengan mampunya siswa memecahkan masalah matematika, siswa makin mampu mengkomunikasikan kemampuan komunikasi matematikanya.

Hasibuan dan Surya (2017) juga menemukan bahwa bahwa ada pengaruh yang signifikan dari pendekatan openended terhadap kreativitas siswa dalam materi fraksional di kelas III SD Negeri 200117 Padangsidimpuan Utara.

Mawaddah, Erlinawaty Simanjuntak Perbedaan Kemampuan Komunikasi Matematis Siswa Melalui Pendekatan Pembelajaran Open Ended Dengan Pendekatan Pembelajaran Differentiated Instruction Berbantuan Wingeomdi SMP Negeri I Tanjung Morawa. Jurnal Inspiratif, Vol. 4, No. 2 Agustus 2018. 
Teori belajar yang mendukung pendekatan Open Ended adalah teori konstruktivistik. Teori ini menekankan pada pentingnya memberikan siswa kesempatan mengungkapkan idenya dengan jalan berdiskusi, menulis, membuat poster dan lain-lain serta siswa diberikan kesempatan untuk mengembangkan motivasi dalam mempelajari suatu topik dengan memberi kesempatan melakukan observasi. Sedangkan teori belajar yang mendukung pendekatan Differentiated Instructionadalah teori Bruner. Slameto (2015:11) menyatakan di dalam proses belajar Bruner mementingkan partisipasi aktif dari tiap siswa dan mengenal dengan baik adanya perbedaan kemampuan. Untuk meningkatkan proses belajar perlu lingkungan yang dinamakan eksplorasi, penemuan-penemuan baru yang belum dikenal atau pengertian yang mirip dengan yang sudah diketahui.

Kedua pendekatan ini menuntut siswa untuk menemukan sendiri pengetahuannya. Oleh karena itu kedua pendekatan ini sangat mampu dalam meningkatkan kemampuan komunikasi matematis siswa. Hal ini didukung oleh penelitian Nelly yang menyimpulkan bahwa penerapan pendekatan DI dapat meningkatkan hasil belajar siswa kelas XI MIPA2 di SMAN 1 Koba, terlihat dari nilai rata-rata akhir siklus secara klasikal sebesar 3,06 dengan KKM 2,67 dan pembelajaran dengan pendekatan DI juga dapat meningkatkan aktivita belajar siswa. Dan juga dari penelitian yang dilakukan Neva Nerissa Arviana bahwa kemampuan pemecahan masalah siswa setelah mengikuti pembelajaran dengan pendekatan Differentiated Instruction yang diterapkan menunjukkan perkembangan yaitu siswa dengan kriteria sangat rendah mengalami perkembangan sebesar 44,76\%, kriteria rendah mengalami perkembangan sebesar $23,2 \%$, kriteria sedang mengalami perkembangan sebesar $10,52 \%$, untuk kriteria tinggi dan sangat tinggi berkembang sebesar $31,6 \%$ dan $23,7 \%$. Hampir seluruh siswa $(87.75 \%)$ memberikan respons positif pada penerapan pembelajaran dengan pendekatan Differentiated Instruction. Selanjutnya penelitian yang dilakukan oleh Hidayatul yang menyimpulkan terdapat perbedaan kemampuan spasial antara siswa yang diberi pembelajaran pendekatan matematik realistik berbantuan aplikasi wingeom dengan pendekatan matematika realistik berbantuan aplikasi cabri, dan juga terdapat perbedaan disposisi matematis antara siswa yang diberi pembelajaran pendekatan matematika realistik berbantuan aplikasi wingeom dengan siswa yang diberi pembelajaran pendekatan matematika realistik berbantuan aplikasi cabri serta aktivitas aktif siswa dengan pembelajaran pendekatan matematika realistik berbantuan aplikasi wingeom sudah efektif.

\section{KESIMPULAN DAN SARAN}

Berdasarkan hasil penelitian yang diperoleh maka peneliti dapat mengambil kesimpulan bahwa rata-rata kemampuan komunikasi matematis siswa yang diajarkan dengan pendekatan Open Ended berbantuan Wingeom $(80,69)$ dan rata-rata kemampuan komunikasi matematis siswa yang diajarkan dengan pendekatan pembelajaran DifferentiatedInstruction berbantuan Wingeom $(73,19)$, sehingga terdapat perbedaan yang diajarkan dengan pendekatan open ended berbantuan wingeom dan differentiated instruction berbantuan wingeom. Berdasarkan simpulan diatas, maka disarankan (1) Kepada pengajar matematika dapat menggunakan

Mawaddah, Erlinawaty Simanjuntak Perbedaan Kemampuan Komunikasi Matematis Siswa Melalui Pendekatan Pembelajaran Open Ended Dengan Pendekatan Pembelajaran Differentiated Instruction Berbantuan Wingeomdi SMP Negeri I Tanjung Morawa. Jurnal Inspiratif, Vol. 4, No. 2 Agustus 2018. 
pendekatan pembelajaran Open Ended berbantuan Wingeom sebagai salah satu alternatif pembelajaran dalam upaya meningkatkan kemampuan komunikasi matematis siswa dalam proses pembelajaran khususnya materi kubus dan balok karena dari hasil penelitian didapat bahwa rata-rata siswa yang diajar dengan pendekatan open ended berbantuan wingeom adalah 80,69 sedangkan yang diajarkan dengan pendekatan differentiated instruction berbantuan wingeom adalah 73,19. (2) Bagi pihak terkait lainnya seperti pihak sekolah diharapkan untuk lebih memperhatikan kelengkapan sarana dan prasarana dalam melancarkan proses pembelajaran seperti laboratorium komputer. Karena salah satu aplikasi yang dapat mempermudah pembelajaran matematika adalah aplikasi wingeom. Dengan menggunakan aplikasi tersebut siswa lebih tertarik, lebih aktif serta lebih antusias dalam pembelajaran.

\section{REFERENSI}

Afandi, A., \&Dhoriva Urwatul Wustqa, (2013), Pendekatan Openended dan Inkuiri Terbimbing ditinjau dari Kemampuan Pemecahan Masalah dan Representasi Multipel Matematis, PYTHAGORAS: Jurnal Pendidikan Matematika, ISSN: 1978-4538, Vol. 8 (1): 1-11

Arviana, Neva Nerissa, (2014), Penerapan Pendekatan Differentiated Instructionuntuk Mengembangkan Kemampuan Pemecahan Masalah Matematika Siswa Kelas VIII SMP Pada Materi Kubus dan Balok, Jurnal Ilmiah Pendidikan Matematika, Vol. 3 (3): 150-157

Harahap, Hidayatul Mazidah, (2016), Perbedaan Kemampuan
Spasial dan Disposisi Matematis antara Siswa yang diberi Pembelajaran Pendekatan Matematika Realistik Berbantuan Aplikasi Wingeom dengan Berbantuan Aplikasi Cabri di MTS Islamiyah Kotapinang, Tesis, UNIMED, Tidak dipublikasikan

Hasibuan, A.M. dan Surya, E. 2017. The Effect of an Open-Ended Approach on Students' Creativity in Fractional Material. International Journal of Sciences: Basic and Applied Research (IJSBAR). Volume 34, No 1, pp 54-63.

Lubis, Hefni Lidia, 2015), Pengaruh Pendekatan Pembelajaran Open-Ended terhadap Kemampuan Pemecahan Masalah dan Berfikir Kreatif Matematis Siswa SMP Negeri 16 Medan, Tesis, UNIMED, Tidak dipublikasikan.

Rizqi, N. R., \& Surya, E. 2017. An Analysis of Students' Mathematical Reasoning Ability In VIII Grade of Sabilina Tembung Junior High School. International Journal of Advance Research And Innovative Ideas In Education (IJARIIE). Vol-3 Issue-2 2017.

Setiawan, Raden Heri dan Idris Harta, (2014), Pengaruh Pendekatan Open Ended dan Pendekatan Kontekstual terhadap Kemampuan Pemecahan Masalah dan Sikap Siswa terhadap Matematika, Jurnal Riset Pendidikan Matematika, Vol. 1 (2): 240-256.

Simamora, R. E., Sidabutar, D. R ., \& Surya, E. 2017. Improving Learning Activity and Students'

Mawaddah, Erlinawaty Simanjuntak Perbedaan Kemampuan Komunikasi Matematis Siswa Melalui Pendekatan Pembelajaran Open Ended Dengan Pendekatan Pembelajaran Differentiated Instruction Berbantuan Wingeomdi SMP Negeri I Tanjung Morawa. Jurnal Inspiratif, Vol. 4, No. 2 Agustus 2018. 
Problem Solving Skill through Problem Based Learning (PBL) In Junior High School. International Journal of Sciences: Basic and Applied Research (IJSBAR). Volume 33, No 2, pp (321-331).

Slameto, 2015, Belajar dan FaktorFaktor yang Mempengaruhi, Renika Cipta, Jakarta

Trianto,

$\begin{array}{lr}\text { 2011,Mendesain } & \text { Model } \\ \text { Pembelajaran } & \text { Inovatif- } \\ \text { Progresif.Penerbit } & \text { Kencana } \\ \text { Prenada Media Group, Jakarta }\end{array}$

Umar, W, (2012), Membangun Kemampuan Komunikasi Matematis dalam Pembelajaran Matematika,Jurnal Ilmiah Prodi STKIP Siliwangi, Vol. 1 (1), Bandung

Yuliana, Nelly, (2017), Pendekatan Differentiated Instruction (DI) dalam Meningkatkan Hasil Belajar dan Aktivitas Matematika Siswa Kelas XI MIPA-2 di SMAN 1 Koba, Indonesia Digital Journal of Mathematics and Education, ISSN: 2407-8530, Vol. 4 (6): 370-378.

Mawaddah, Erlinawaty Simanjuntak Perbedaan Kemampuan Komunikasi Matematis Siswa Melalui Pendekatan Pembelajaran Open Ended Dengan Pendekatan Pembelajaran Differentiated Instruction Berbantuan Wingeomdi SMP Negeri I Tanjung Morawa. Jurnal Inspiratif, Vol. 4, No. 2 Agustus 2018. 